\title{
Makna Allah Pencipta Manusia dan Problematika Arti Kata 'Kita' dalam Kejadian 1:26-27
}

\author{
Juliman Harefa \\ Sekolah Tinggi Teologi Banua Niha Keriso Protestan Sunderman, Nias \\ julimanh24@sttsundermann.ac.id
}

\begin{tabular}{l} 
Article History \\
Received: \\
05 November 2019 \\
Revised: \\
15 November 2019 \\
Published: \\
November 2019 \\
\hline \\
Keywords \\
(Kata kunci): \\
Elohim; \\
exegesis; \\
Genesis; \\
God; \\
hermeneutic; \\
Allah; \\
eksegese; \\
hermeneutik; \\
Kejadian
\end{tabular}

33991/epigraphe.v3i2.129

\begin{abstract}
This paper is an exegetical study of the book of Genesis 1:26-27, to understand whom God created, why God created a man who is called a noble creature, and studies the meaning of being pictured and similar to God. The study uses the hermeneutic spiral method (from text to context) to reveals the meaning of the original text of the Bible. Also, the implementation of the meaning of the original text today. The study of the text of the word Elohim, Yahweh/Adonay, and We contains the notions of the purity, omnipotence, majesty, and glory of the creator of the universe. The creator God created humans in His image and likeness so that humans have "divine potential" that is not possessed by other creatures. The divine potential is the human selfimage that has a soul that will understand as the quality of human resources themselves, namely the potential for spirituality, ratios, wills that will apply in the secular, cultural, and educational world in this millennial era.
\end{abstract}

Keywords: Elohim; exegesis; Genesis; God; hermeneutic

Abstrak
Artkel ini merupakan studi eksegetis kitab Kejadian 1:26-27, untuk
memahami tentang siapa Allah pencipta, mengapa Allah menciptakan
manusia yang disebut sebagai makhluk mulia dan mengkaji makna segam-bar
dan serupa dengan Allah. Kajian ini menggunakan metode herme-neutik
spiral (dari teks kepada konteks) yaitu studi eksegetis yang mengungkap
makna teks asli Alkitab dan implementasi makna teks asli pada masa kini.
Kajian teks kata Elohim, Yahwe/Adonay dan Kita mengandung arti
kemahasucian, kemahakuasaan, keagungan dan kemulia-an Sang Pencipta
alam semesta. Allah Pencipta menciptakan manusia me-nurut gambar dan
rupa-Nya, sehingga manusia memiliki "potensi ilahi" yang tidak dimiliki oleh
makhluk lain yang diciptakan oleh Allah. Potensi ilahi adalah citra diri
manusia yang memiliki jiwa akan dipahami sebagai kualitas
sumberdaya manusia itu sendiri yakni potensi spiritualitas, rasio,
kehendak yang akan diaplikasikan dalam dunia sekuler, budaya dan
pendidikan di era milenial.
Kata-kata kunci: Allah; eksegese; Elohim; hermeneutik; Kejadian




\section{Pendahuluan}

Yongky Karman menulis sebuah jurnal yang berjudul Hidup Manusia menurut Perjanjian Lama. Uraiannya tentang "pembentukan" manusia menurut Kejadian 2:7. menyatakan proses penciptaan menusia terbagi dalam dua narasi. Narasi pertama adalah kejadian 1:26-27 dan yang kedua adalah Kejadian 2:7. Narasi pertama menguraikan manusia sebagai makhluk mulia karena diciptakan segambar dan serupa dengan Allah. Sedangkan pada narasi kedua manusia dinyatakan sebagai bagian dari alam karena dibentuk dari tanah(berasal dari alam). Oleh sebab demikianlah, secara eksegetis, manusia pertama itu diberi nama Adam. ${ }^{1}$ Akan tetapi dalam tulisan tersebut Karman tidak menguraikan alasan hakiki mengapa manusia disebut sebagai makhluk mulia secara eksegetis; mengapa manusia diciptakan menurut gambar dan rupa Allah.

Bertitik tolak dari hal tersebut di atas, tulisan ini hendak memaparkan bagaimana manusia disebut sebagai makhluk mulia dan diciptakan dengan mengambil gambar dan rupa Allah sendiri sebagaimana diungkapkan di dalam Kejadian 1:26-27. Analisis diarahkan untuk melihat implementasi konteks tersebut di masa kini. Untuk mencapai tujuan dimaksud, tulisan ini akan menganalisis teks Kejadian 1:26-27 untuk menjawab pertanyaan yang berkaitan dengan hubungan antara Elohim dengan kata Kita, dan untuk mencari tahu alasan dibalik penciptaan manusia yang segambar dan serupa dengan Dia.

\section{METODE}

Tulisan ini menggunakan metode spiral hermeneutika ${ }^{2}$ (dari teks kepada konteks) teori yang dikembangkan oleh Grant R. Osborn, yaitu studi eksegetis yang mengungkap makna teks asli Alkitab kepada kontekstualisasi (implementasi) makna teks asli.untuk memperoleh makna kata Allah sebagai gelar Allah pencipta, pengertian istilah kata "Kita", makna segambar, serupa dengan Allah dan signifikasinya. Analisis dilakukan dengan meneliti teks di dalam bahasa Ibrani untuk kemudian merumuskan maknanya dengan mengangkat kata-kata kunci yang ada di dalam teks. Tinjauan literatur dilakukan untuk melengkapi analisis sehingga tersusun jawaban atas pertanyaan penelitian.

\section{Kajian Teks Kejadian 1:26-27}

\section{Allah Pencipta}

Kejadian 1: 26

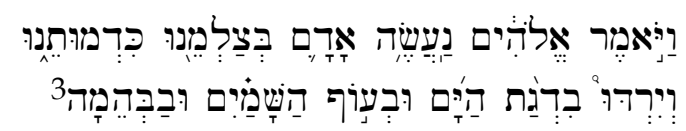

(Dan Allah berfirman, marilah kita menjadikan manusia di dalam gambar kita seperti rupa kita dan mereka akan memerintah pada ikan laut itu dan pada unggas langit itu dan pada ternak pada seluruh bumi itu dan pada seluruh yang melata binatang merayap atas bumi itu).

\footnotetext{
${ }^{1}$ Yonky Karman, "Hidup Manusia Menurut Perjanjian Lama,” Forum Biblika, Jurnal Ilmiah (2013).

${ }^{2}$ Grant R. Osborn, Spiral Hermeneutika, Pengantar Konprehensif Bagi Penafsiran Alkitab, Pertama. (Surabaya: Penerbit Momentum, 2012), 1-16.

${ }^{3}$ Lembaga Alkitab Indonesia, Perjanjian Lama Ibrani - Indonesia (Jakarta: LAI, 2002).
} 


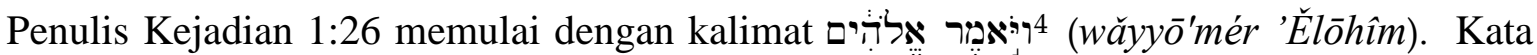
וּיאֵֵָר (wăyyō'mér) berasal dari akar katarma(amar) artinya berkata merupakan kata kerja bentuk qal imperfek orang ketiga maskulin tunggal, yang didahului oleh awalan

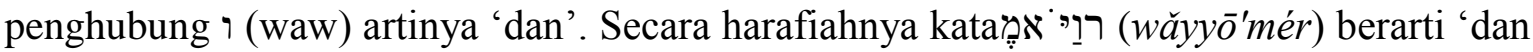
ia berkata (to say)., ${ }^{5}$ Karena itu Ia yang berkata adalah אלדָים ' ('Ělōhîm), maka katarm;a'yang artinya berkata atau berfirman mengandung makna yang sangat penting karena perkataan-Nya itu terciptalah terang dan memisahkan terang itu dari gelap dan juga dengan perkataan-Nya (Firman) Ia menciptakan makhluk-makhluk, Ia adalah Allah pencipta. ${ }^{7}$

Paul Enns menjelaskan bahwa teks tersebut di atas berkaitan dengan ayat 1 pada kejadian pasal 1 yang menyatakan "pada mulanya adalah Allah", yang memperkenalkan diri-Nya sebagai Elohim. Kata Elohim tersebut menyatakan Allah adalah subjek dan objek. Sebagai Subjek, Allah adalah pencipta alam semesta dan manusia dan sebagai objek, Allah adalah Tuhan yang dipecaya, dihormati dan "ditakuti" tentu Allah yang dipuji dan disembah oleh umat manusia yang percaya pada-Nya. ${ }^{8}$ Teks menunjukkan pula bahwa Allah atau Elohim adalah yangpencipta alam semesta dalam satu kronologi yang dirancang oleh Allah buat. Penggunaan kalimat "pada mulanya",membuktikan adanya rangkuman dari sebuah proses yang panjang dalam persitiwa penciptaan. Allah juga melakukan konfirmasi atas seluruh kronologi penciptaan itu di dalam naskah Kejadian untuk meneguhkan kredibilitasnya sebagai pencipta. Beberapa dukungan itu terlihat melalui pernyataan bahwa semuanya sungguh amat baik (Kej. 1:31), mendelegasikan kekuasaan atas bumi kepada manusia (1:26), berbicara kepada manusia muka dengan muka (1:28-30), menciptakan tempat bagi manusia (1:3-25; 29-30), menguji manusia (2:16-17), mencari dan menemukan manusiayang bersembunyi karena dosa (3:9).

Keyakinan akan Allah sebagai pencipta dikuatkan melalui penggunaan kata kerja 'bara' di dalam teks. Enam kali kerja ini dipakai.Pertama kali untuk mengatakan permulaan dari segala sesuatu (Kej 1:1), kedua, untuk merangkum segenap pekerjaan Allah (2:3), ketiga,untuk menceritakan permulaan hidup hewan ( 1:21), ketiga, keempat, kelima dan keenam berkisar pada penciptaan manusia menurut gambar Allah. Hal tersebut menguatkan eksistensiNya sebagai pencipta segala sesuatu. Hal ini juga terlihat dari salah satu statemen iman Yahudi. Menurut Felshin pernyataan iman Yahudi yang mengatakan "I believe with perfect faith that the creator, blessed be his name, is the Author and Guide of everything that has been created, and that he alone has made, does make and will make all

${ }^{4}$ LAI, Perjanjian Lama Ibrani - Indonesia, Kedua. (Jakarta: Lembaga Alkitab Indonesia, 2002), http://www.alkitab.or.id.

${ }^{5}$ James Strong, The New Strong's Complete Dictionary of Bible Words (USA: Thomas Nelson Publisher, 1996), 311.

${ }^{6}$ Strong, The New Strong's Complete Dictionary of Bible Words.

${ }^{7}$ A.A. Sitompul Baker, D. L., S.M. Siahaan, Pengantar Bahasa Ibrani, Ke-25. (Jakarta: BPK Gunung Mulia, 2015).

${ }^{8}$ Paul Enns, Moody Handbook of Theology, ed. Rahmiati Tanudjaja (penerjemah), 5th ed. (Malang: Literatur SAAT, 1989), 43. 
thing" adalah sebuah legitimasi kredibiltas Allah sebagai pencipta. ${ }^{9}$ Dalam kapasitas demikian, Brueggemann menegaskan bahwa kekuasaanNya sungguh luar biasa dan tidak tertandingi oleh kuasa manapun di muka bumi. Dia menjadi seorang creator bagi dunia dan dengan sendirinya manusia dituntut untuk ambil bagian melestarikan hasil ciptaanNya itu. ${ }^{10}$

\section{Nama Allah Israel}

Baker menjelaskan bahwa bahwa אלדהים adalah jenis eksistensi ilahi yang menyatakan bahwa Dia adalah Allah bukan menusia, atau makhluk yang lain. ${ }^{11}$ James menguraikan pula אֵלה adalah nomina jamak yang berfungsi sebagai nomina tunggal. Apabila digunakan dan diubah pada rangkaian jamak dan bentuk verba jamak akan menunjuk pada ilah-ilah bangsa-bangsa lain, ${ }^{12}$ karena Elohim dapat dipakai dalam bentuk tunggal, yang berarti Allah yang yang Mahatinggi, yang mengacu kepada hubungannya dengan kosmik dan semester dunia (Kej 1:1). ${ }^{13}$

Ketika Musa bertanya kepada Allah tentang nama-Nya. Allah memperkenalkan nama-

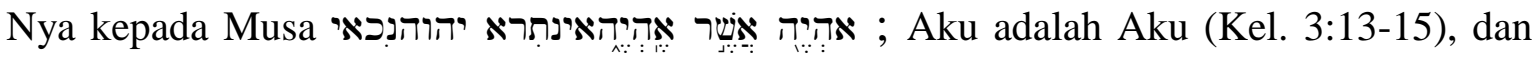

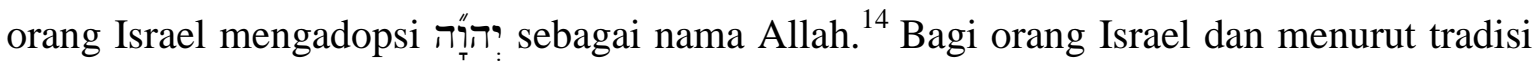
Yahudi hwhy adalah nama yang mahasuci dan mulia tidak boleh disebutkan dengan sembarangan seperti yang tertulis dalam Kel. 20:7 berbunyi: "Jangan menyebut nama-Ku dengan sembarangan, sebab Aku, TUHAN Allahmu, menghukum siapa saja yang menyalahgunakan nama-Ku" (BIS).

Oleh karena itu hwhy diucapkan dengan אֶרנִ ((adonay) artinya TUHAN, Yehovah atau Yahweh. Baker menjelaskan proses tersebut di atas, bahwa tanda vokal yang terdapat

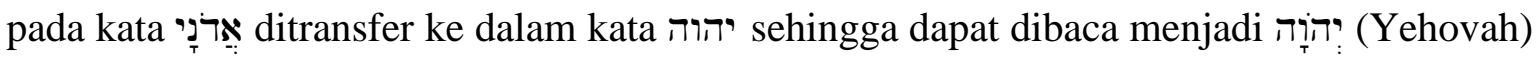
diterjemahkan dengan kata TUHAN. ${ }^{15}$ Sedangkan Kelly menjelaskan bahwa dalam kata

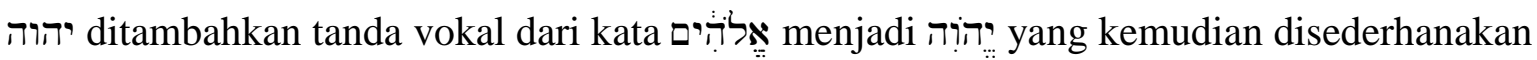
menjadi hwIhy>diterjemahkan dengan kata ALLAH. ${ }^{16}$ Jadi, nama Allah Israel dalam Alkitab yang ditulis dengan huruf kapital TUHAN ataupun ALLAH adalah terjemahan

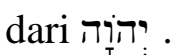

\section{Makna Kata Kita}

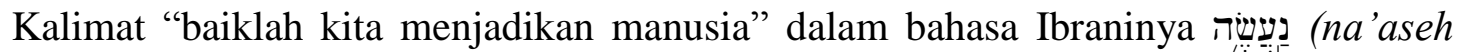
adam), kata עָָָָ adalah qal, imperfek, orang pertama jamak, artinya membuat (to do, to

\footnotetext{
${ }^{9}$ Moses Maimonides and Max Felshin, Moses Maimonides (Rambam) (New York: Book Guild, 1956), 203.

${ }^{10}$ Walter Brueggemann, Teologi Perjanjian Lama: Kesaksian, Tangkisan, Pebelaam, Pertama. (Yogyakarta: CV. Titian Galang Printika, 2009), 224.

${ }^{11}$ Baker, D. L., S.M. Siahaan, Pengantar Bahasa Ibrani.

${ }^{12}$ Page H. Kelley, Ibrani Biblikal, Pertama. (Surabaya: Penerbit Momentum, 2013).

${ }^{13}$ J.D. Douglas, Ensiklopedi Alkitab Masa Kini, Jilid 1, A-L, ed. F.F. Bruce (Leicester, England: The Inter-arsity Fellowship, 1982), 38.

${ }^{14}$ Strong, The New Strong's Complete Dictionary of Bible Words.

${ }^{15}$ Baker, D. L., S.M. Siahaan, Pengantar Bahasa Ibrani.

${ }^{16}$ Page H. Kelley, Ibrani Biblikal, 39-40.
} 
make). ${ }^{17}$ Jadi, kata "kita" dalam kalimat tersebut adalah berbentuk jamak. Menurut The interpreter's Bible of the book of Genesis, kata kita dalam kalimat itu adalah Tuhan dengan oknum ilahi lainnya yang adalah bagian dari keberadaannya sendiri. ${ }^{18}$ Senada dengan itu, Gutrie menjelaskan pula bahwa bentuk jamak dari oknum pertama (kita) itu agaknya harus diterjemahkan demikian, bahwa sang Pencipta berfirman sebagai raja Sorgawi disertai oleh bala tentara sorgawi. ${ }^{19}$ D.A. Carson menafsirkan bentuk jamak "Kita" dalam teks ini adalah menunjuk kepada malaikat. ${ }^{20}$ Menurut Webster bentuk jamak "Kita" secara implisit menunjuk pada suatu kenyataan ketritunggalan Allah. ${ }^{21}$

Akan tetapi Telnino melihat dari pendekatan yang berbeda. Dijelaskannya bahwa kita di dalam Kejadian 1:26 berasal dari kata Ibrani na'aseh yang diterjemahkan secara literal sebagai upaya bersama-sama untuk mengerjakan sesuatu dari yang tidak ada menjadi ada (atau "kita akan menjadikan"). Upaya tersebut melambangkan pekerjaan yang berkesinambungan. Telnoni menghubungkannya dengan Elohim dalam Kejadian 1:1 sebagai bagian yang tidak terpisahkan. Artinya, 'Kita' yang dimaksud adalah Elohim yang bentuk jamaknya tidak mewakili Trinitas ${ }^{22}$. Telnino menolak pendapat Webster yang merujuk kata kita kepada Allah Tritunggal.

Hasil dari tugas eksegesememperlihatkan bahwa yang dimaksud dengan kata Kita

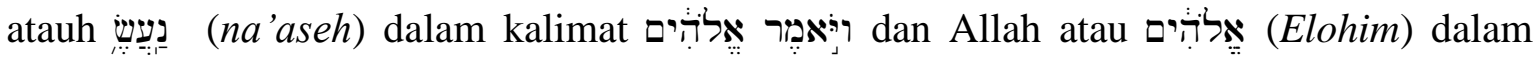

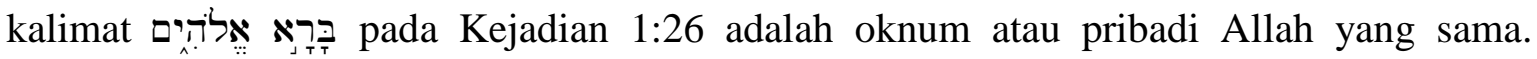

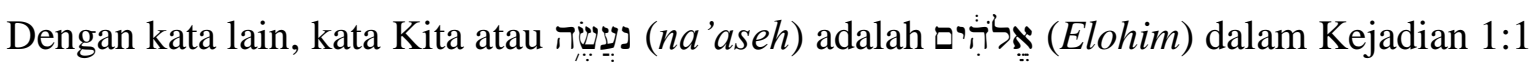
demikian juga sebaliknya. Hal tersebut dipertimbangkan karena hasil eksegese dimana

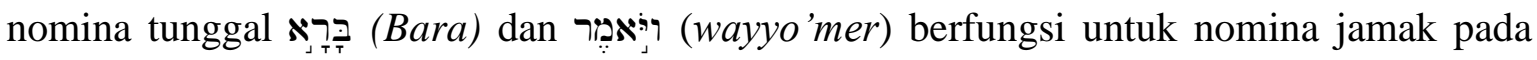

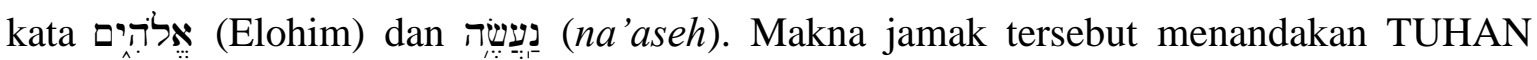
Allah semesta alam yang mahasuci dan mahakuasa. ${ }^{23}$

\section{Manusia Diciptakan Menurut Gambar dan Rupa Allah}

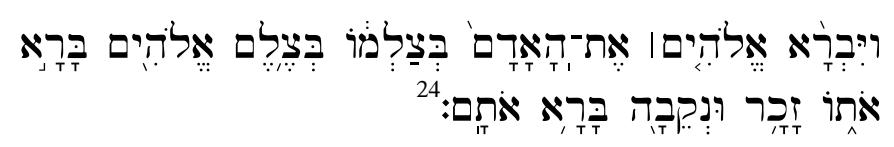

(Dan Allah menciptakan manusia dalam gambar-Nya di dalam gambar Allah Dia menciptakan-Nya laki-laki dan perempuan Dia menciptakan mereka).

\footnotetext{
${ }^{17}$ Strong, The New Strong's Complete Dictionary of Bible Words.

${ }^{18}$ George Arthur (ed board) Buttrick, “The Interpretter's Bible, Vol.1” (New York: Nashville: Abingdon Press, 1952), 483.

${ }^{19}$ Donald Gutrie, Tafsiran Alkitab Masa Kini 1, Kejadian-Ester (Jakarta: Yayasan Komunikasi Bina Kasih, 2000), 82.

${ }^{20} \mathrm{D}$ A Carson, New Bible Commentary (USA: Intervarsity Press, 1994), 61.

${ }^{21}$ Carson, New Bible Commentary.

${ }^{22}$ J.A. Telnoni, Kejadian Pasal 1-11, Tafsiran Alkitab Kontekstual-Oikumenis, Ke-1. (Jakarta: Bpk Gunung Mulia, 2017), 55-56.

${ }^{23}$ Baker, D. L., S.M. Siahaan, Pengantar Bahasa Ibrani.

${ }^{24}$ LAI, Perjanjian Lama Ibrani - Indonesia.
} 
Kata 25 (bara) adalah kata kerja qal perfec, orang ketiga tunggal, maskulin. Artinya menciptakan, kata ini hanya ditujukan kepada karya Allah saja untuk membedakan keunggulan ciptaan Allah bila dibandingkan dengan karya manusia. ${ }^{26}$ Kata kerja רָּר (bārā) sangat khas dalam Perjanjian Lama. Di dalam bahasa-bahasa yang serumpun dengan bahasa Ibrani istilah ini tidak ditemukan, melainkan hanya istilah yang lebih umum artinya seperti banu (mendirikan) dalam bahasa Akkad (Mesopotamia). Sedangkan dalam bahasa Ibrani sendiri istilah bārā' hanya dipakai mengenai karya Allah termasuk manusia (' $\sim \mathrm{d}$ "a'h))', untuk menyatakan keunggulan penciptaanNya dibanding dengan hasil karya manusia. Allah dapat menciptakan $\left(b \bar{a} r \bar{a}{ }^{\prime}\right)$ sesuatu yang sama sekali baru, sedangkan manusia hanya mampu membuat ( $\bar{a} s \bar{a})$ sesuatu dari bahan yang sudah diciptakan Allah. ${ }^{27}$

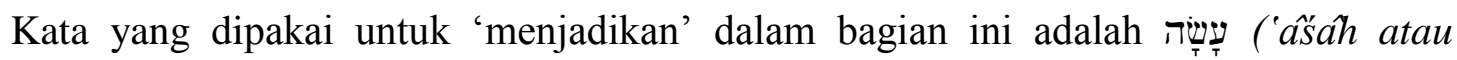
$n \breve{a}$ 'ášé[h]), merupakan kata kerja qal imperfek orang pertama jamak dari kata ('ấsa $[h]$ ) 'membuat, menjadikan.' Istilah (nă 'ăsé $[h]$ ), secara harafiahnya berarti 'kita membuat, menjadikan. ditemukan dalam PL 2600 kali. Istilah ini adalah umum, dan dipergunakan baik untuk pekerjaan manusia maupun karya Allah (band.Kej. 1:31).

Walaupun ada penjelasan lain dari Stephen Tong bahwa kata "menciptakan" yang dipakai dalam bahasa Ibrani dalam kejadian 1:26-27 sama dengan kata "menciptakan" dalam Kejadian 1:1, yaitu kata "bara”. Ada beberapa kata dalam bahasa Ibrani untuk kata "cipta" yaitu "bara", "yatsag" dan "asyah". ${ }^{28}$ Tong menjelaskan maksudnya bahwa kata bara, yatsag dan asyah digunakan untuk maksud yang berbeda. Bara digunakan untuk menciptakan dari yang tidak ada menjadi ada atau diciptakan dari ketidakberadaan (creation ex nihilo) sedangkan yatsag dan asyah menciptakan dari materi yang sudah ada.

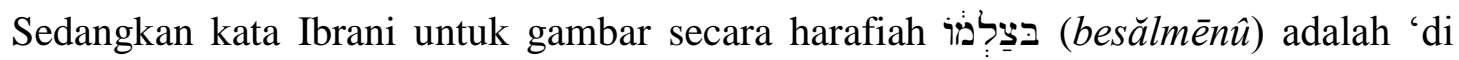
dalam gambar kita', LAI terjemahan lama menerjemahkan 'atas peta.' dari kata צֶ. בֶֶם ' (tsělěm) ${ }^{29}$ Kata tsělěm ini diturunkan dari akarkata yang memiliki makna "mengukir" atau "memotong." ${ }^{30}$ Dalam konteks sosial Timur Dekat kuno 'gambar'(tsělěm) biasa dimaksud sebagai bentuk fisik yang mewakili kehadiran seorang penguasa. Ketika seorang raja menguasai wilayah di luar kerajaannya, kehadirannya secara fisik di wilayah itu biasa diwakili dengan sělěm berupa patung dirinya yang ditaruh di daerah itu. Patung itu bukan raja sebenarnya, melainkan biasa dipandang sebagai representasi kehadirandalam lingkup geografis kekuasaan. ${ }^{31}$ Sehingga dalam kaitannya dengan penciptaan, berarti "peta/gambar". Konotasi yang sama dipakai dalam kata Image (Inggris) atau mophe (Yunani) yang artinya suatu peta yang memiliki bentuk atau pola tertentu. ${ }^{32}$

\footnotetext{
${ }^{25}$ Strong, The New Strong's Complete Dictionary of Bible Words.

${ }^{26}$ Baker, D. L., S.M. Siahaan, Pengantar Bahasa Ibrani, 82.

${ }^{27}$ Yonky Karman, Bunga Rampai Teologi Perjanjian Lama (Jakarta: BPK Gunung Mulia, 2013), 31.

${ }^{28}$ Stephen Tong, Peta Dan Teladan Allah (Surabaya: Momentum, 2012), 1-2.

${ }^{29}$ Strong, The New Strong's Complete Dictionary of Bible Words.

${ }^{30}$ Anthony A. Hoekema, Manusia: Ciptaan Menurut Gambar Allah, Kelima. (Surabaya: Momentum,

${ }^{31}$ Louis Berkhof and Teologi Sistimatika, Doktrin Tentang Gereja, vol. 5 (Jakarta: BPK GM, n.d.), 16.

${ }^{32}$ Tong, Peta Dan Teladan Allah, 13-34.
} 2015), 16-17. 
Akan tetapi model penjelasan kehadiran bentuk fisik dalam budaya Timur Dekat kuno tersebut secara logika agak sulit diterima sebagai representatif Allah ditengah ciptaan. Model tersebut jarang ditemui di dalam Alkitab.Kehadiran Allah lebih sering dijelaskan dalam bentuk kemuliaan-Nya. Contohnyatiang awan yang memimpin perjalanan bangsa Israel pada waktu siang dan malam hari dipadang gurun. Juga dalam bentuk teofaniseperti "perkelahian" antara Allah dan Yakub. Munculnya malaikat pada peristiwa tertentu dalam Alkitab dan fenomena supernatural di atas puncak Sinai, kemah maha suci dan tabut perjanjian adalah bukti manifestasi kehadiran Tuhan. Sehingga, menafsirkan makna tselem dan demutthkepada kemiripan fisik merupakan interpretasi yang lemah. ${ }^{33}$

Tentang pemakaian kata tsělěm ini, menurut Hoekema, "kata ini bisa dipakai untuk mendeskripsikan ukiran berbentuk binatang atau manusia. Ketika diaplikasikan pada penciptaan manusia di dalam Kejadian 1, kata tsělěm ini mengindikasikan bahwa manusia menggambarkan Allah. Artinya manusia merupakan suatu representatif Allah." 34 Demikian halnya pendapat Sands yang menyimpulkan bahwa segambar dan serupa dengan Allah memiliki esensi yang sama, ${ }^{35}$ yang menjadi satu kesatuan yang berpusat dalam di Yesus Kristus dalam inkarnasiNya. ${ }^{36}$

Sedangkan kata Ibrani untuk rupa דִ דמוּת $\left(d^{e} m \hat{t} t\right)^{37}$ di dalam Kejadian 1:26 memiliki makna "menyerupai." ${ }^{38}$ Bisa dikatakan bahwa kata $d^{e}$ mût" di dalam Kejadian 1:26 mengindikasikan bahwa gambar tersebut juga merupakan keserupaan artinya menyerupai sesuatu. Pengertian lainnya adalah likeness (Inggris), Schema (Yunani) dalam artian mirip dengan bentuk, dalam arti, sesuatu model yang harus dalam bentuk yang pertama, maknanya adalah hidup manusia yang harus sesuai dengan bentuk ukuran yang

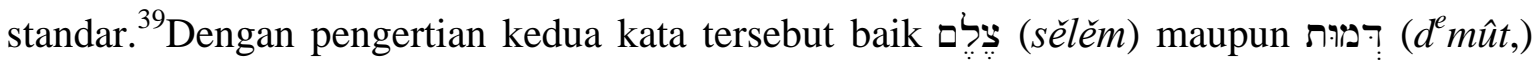
mendeskripsikan bahwa manusia sebagai ciptaan yang dicipta di dalam gambar menurut rupa Allah adalah representasi Allah yang "menyerupai” Dia. Dengan kata lain, kehidupan manusia seutuhnya merujuk kepada standar Allah sebagai Pencipta.

Dalam ayat 27, kata yang dipakai 'menurut gambar-Nya' adalah sama dengan bentuk kata gambar yang dipakai dalam ayat 26. Tetapi dalam ayat 27 mendapatkan suffix orang ketiga maskulin tunggal. Secaraharafiah kata ini diterjemahkan "di dalam gambar-Nya". LAI TB menerjemahkan "menurut gambar-Nya." LAI TL menerjemahkan kata besălmô" atas petanya."Oleh beberapa versi seperti KJV,NAS, NIV diterjemahkan in his own image.Pemakaian kata gambar maupun rupa dalam Alkitab terkadang dipakai secara bersama-sama dan terkadang dipakai salah satunya. ${ }^{40}$ Dengan demikian dapat dikatakan

\footnotetext{
${ }^{33}$ I Putu Ayub Darmawan, “Murid Yang Memuridkan” in Melaksanakan Amanat Agung Di Abad 21, ed. I Putu Ayub Darmawan (Ungaran: Sekolah Tinggi Teologi Simpson, 2017), 104.

${ }^{34}$ AA Hoekema, "Manusia: Ciptaan Menurut Gambar Allah,” Terj. Irwan (2003): 17, http://www.momentum.or.id/images/files/Manusiacipataan.pdf.

${ }^{35}$ Hoekema, "Manusia: Ciptaan Menurut Gambar Allah."

${ }^{36}$ D. Robinson, "Understanding the 'Imago Dei'.," no. 24 February 2016 (2010).

${ }^{37}$ Strong, The New Strong's Complete Dictionary of Bible Words.

${ }^{38}$ Charles F. Pfeiffer dan Everett F. Harrison, Commentary Alkitab Wycliffe (Jakarta: Gandum Mas, 2007), 29.

${ }^{39}$ Tong, Peta Dan Teladan Allah, 14-15.

${ }^{40}$ Hoekema, Manusia: Ciptaan Menurut Gambar Allah, 18.
} 
bahwa, baik 'gambar' maupun 'rupa' biasa dipakai secara sinonim, bergantian untuk pengertian yang sama.Maka arti diciptakan dalam gambar Allah adalah manusia diciptakan "seperti" Allah dalam pengertian "memiliki" potensi yang dimiliki Allah dalam hal spiritual, rasio, mampu berkomunikasi dan ber-eksistensi seperti yang dikatakan oleh Buttrick berikut. The image included likeness to them in spiritual powers-the power of the thought, the power of communication, the power of self-transcendent. ${ }^{41}$

Sementara itu, Barth memberikan kesimpulan bahwa manusia diciptakan menurut gambar dan rupa Allah untuk memungkinkan adanya hubungan timbal balik antara Allah dan manusia ${ }^{42}$. Terdapat dua pertimbangan yakni : Pertama, kata Ibrani tselem menekankan kemiripan dan dipakai untuk anak yang serupa dengan bapaknya (Kej. 5:3) dan patung yang menyerupai pembesar. Alkitab berbicara tentang mata, mulut, hidung, wajah, tangan Tuhan. Akan tetapi, bahasa kiasan ini tidak boleh terlalu dipahami secara harfiah. Kedua, di antara para mahkhluk, hanya manusia yang berbicara, berpikiran, mengingat, merencanakan, dan menghasilkan kesenian. Dalam hal inilah dikatakan manusia serupa dengan Allah. ${ }^{43}$

Penciptaan manusia adalah pekerjaan yang dilakukan oleh Allah sendiri, atas kehendak dan inisiatif-Nya.Allah menciptakan manusia menurut gambar dan rupa-Nya, supaya manusia dapat merepresentatifkan Allah di dunia.Dengan demikian wajar manusia memiliki sifat dan karakter seperti yang Allah miliki termasuk spiritual, rasio, kehendak dan moralitas. Dalam hal merepresentatifkan Allah di dunia, Allah di dalam Tuhan Yesus Kristus menjadi sama seperti manusia di dalam dan melalui inkarnasi-Nya. Tuhan Yesus Kristus menurut Darmawan seperti mentor yang men-delegasikan pelayanan kepada para murid-Nya. Seperti penugasan yang diberikan kepada Paulus, Timotius, dan Titus serta pengutusan tujuh puluh murid. ${ }^{44} \mathrm{Hal}$ inilah yang membuat manusia berbeda dari makhluk lainnya. Perbedaan tersebut terletak pada penciptaan manusia menurut gambar dan rupa Allah sedangkan binatang tidak. Itu sebabnya manusia pada lingkup tertentu menjadi rekan sekerja Allah di dunia.

\section{Pembahasan}

\section{Implementasi Kejadian 1:26-27}

Dalam ayat 26 terdapat kata kunci yang menjadi jembatan untuk implementasi

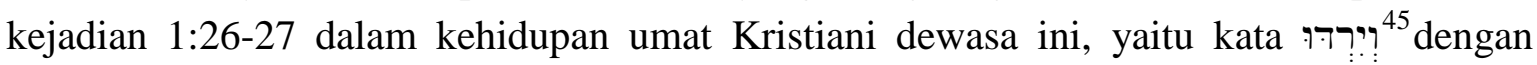
awalan 9 dari akar kata kerja רדה qal imperfek orang ke 3 maskulin tunggal untuk nomina jamak, artinya berkuasa (to rule).

\footnotetext{
${ }^{41}$ Buttrick, "The Interpretter's Bible, Vol.1."

${ }^{42}$ Barth Christoph and Frommel Barth, Teologi Perjanjian Lama 2 (Jakarta: BPK Gunung Mulia, 2016), 34.

${ }^{43}$ Barth Christoph and Frommel Barth, Theologi Perjanjian Lama 1 (Jakarta: BPK Gunung Mulia, 2011).

${ }^{44}$ Darmawan, “Murid Yang Memuridkan” in Melaksanakan Amanat Agung Di Abad 21, 40.

${ }^{45}$ S.T.D. James Strong, LL.D., The New Strong's Complete Dictionary of Bible Words (USA: Thomas Nelson Publisher, 1996), 516 Strong's 7287.
} 


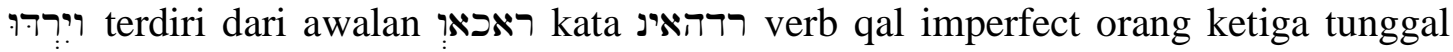
masculine plural, artinya berkuasa dalam bahasa Inggris dominion. Terminologi berkuasa dalam The Reformation Study Bible dijelaskan sebagai God gave humans the culture mandate to rule the creation as benevolent king (9:2; 8:5-; Hebrew 2:5-9). ${ }^{46}$ Artinya Allah memberikan mandat budaya kepada manusia untuk menata ciptaan seperti seorang raja yang baik hati tetapi memiliki potensi ilahi di dalam dirinya.

Potensi ilahi tersebut adalah spiritualitas, rasio, mampu berkomunikasi, memungkinkan adanya hubungan timbal balik antara Allah dan manusia.Manusia dapat berbicara, berpikir, mengingat, merencanakan, dan menghasilkan kesenian. Manusia dapat "merepresentasikan" Allah di dunia, Manusia memiliki sifat dan karakter seperti yang Allah miliki termasuk spiritual, rasio, kehendak dan moralitas, dan juga adanya relasi antara Pencipta dan ciptaan, serta relasi antar ciptaan.

Menata ciptaan dengan potensi ilahi artinya menata "dunia" dalam konteks kekinian yang ditawarkan adalah dunia sekuler masa kini yang telah terkontaminasi dengan sekularisme. Dalam tulisannya berjudul Mengkritisi Teologi Sekularisme, Zaluchu menjelaskan bahwa teologi sekularisasi memberikan kebebasan masyarakat dari ikatan "legalisme", selama tidak menyimpang menjadi sekularisme dan ekstrimnya ke arah ateisme dan jebakan-jebakan lainnya. ${ }^{47}$ Untuk itu manusia dituntut menjaga hakikatnya sebagai makhluk mulia dan berharga dengan tetap bergantung dan percaya kepada Allah sendiri. Bukan justru menjadi sekular sebagaimana diungkapkan Zaluchu di atas.

Pada akhirnya Implementasi penataan ciptaan harus dimulai dalam lingkup terkecil ciptaan yakni keluarga sebagai komunitas. Seperti halnya ketika dulu Allah membentuk Adam dan Hawa sebagai keluarga dan memberikan mandat kepada komunitas kecil tersebut untuk menguasai bumi (dominion mandate). Itu sebabnya muncul penegasan di dalam Keluaran 6:4-9 yang berbunyi: "Dengarlah, hai orang Israel: TUHAN itu Allah kita, TUHAN itu Esa,KasihilahTUHAN, Allahmu, dengan segenap hatimu dan dengan segenap jiwamu dan dengan segenap kekuatanmu.Apa yang kuperintahkan kepadamu pada hari ini haruslah engkau perhatikan haruslah engkau mengajarkannya berulang-ulang kepada anakanakmudan membicarakannya apabila engkau duduk di rumahmu, apabila engkau sedang dalam perjalanan, apabila engkau berbaring dan apabila engkau bangun.Haruslah juga engkau mengikatkannya sebagai tanda pada tanganmu dan haruslah itu menjadi lambang di dahimu,dan haruslah engkau menuliskannya pada tiang pintu rumahmu dan pada pintu gerbangmu."

\section{Kesimpulan}

אֵלהִים (Elohim) adalah gelar keilahian Allah yakni Pencipta. Bangsa Israel percaya

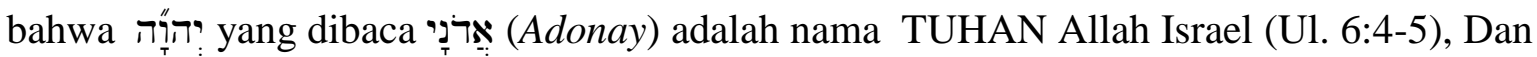
juga nama tersebut dapat dikombinasikan dengan penulisan Tuhan ALLAH dari kata יהו!:

\footnotetext{
${ }^{46}$ Keith Mathison (Associate Editor) R.C. Sproul (General Editor), ed., The Reformation Study Bible (Lake Mary, FL, USA: Ligonier Ministry, 2005).

${ }^{47}$ Sonny Eli Zaluchu, "Mengkritisi Teologi Sekularisasi," Kurios (Jurnal Teologi dan Pendidikan Agama Kristen Vol. 4, no. 1 April 2018 (2018): 26-38, http://www.sttpb.ac.id/ejournal/index.php/kurios/article/view/31.
} 
(atau Yehowah, Yahweh, Yehwih). Makna Penjamakan pada kata TUHAN dan ALLAH menunjuk kepada tetragrammaton יהוּ TUHAN Allah atau Tuhan ALLAH semesta alam yang mahasuci, mahakudus, mahamulia dan mahakuasa, Ia adalah pencipta Alam semesta dan seluruh isinya. Kata נעשֵֶׁ (na'aseh) artinya adalah "Kita" mengandung beberapa arti dan makna; Menunjukkan keberadaan Allah yang ilahi, keberadaan Allah yang jamak kemulian. Pada prinsipnya Pencipta adalah Allah yang Esa dan tidak ada pencipta selain dari Allah (Elohim), dengan kata lain oknum Allah pencipta bukan tiga atau lebih. Allah

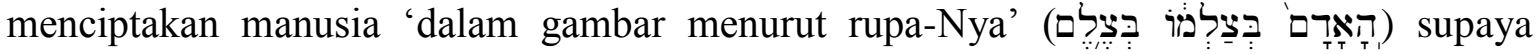
manusia dapat bersekutu Allah dengan memerintah atas bumi supaya terjalin relasi di antara manusia dan Allah berbeda dengan mahkluk-mahkluk lain. Hakikat menjadi gambar Allah berarti tanggung jawab menata atau mengatur ciptaan. Diciptakan menurut gambar Allah berarti manusia adalah citra Allah yang memiliki "potensi" ilahi yakni; Spiritualitas, rasio, kehendak, mampu berkomunikasi, relasi, berpikir, mengingat, merencanakan, jiwa seni, inovasi, dan kreativitas, yang dapat digunakan untuk menata ciptaan dari zaman ke zaman, dan dari generasi ke generasi.

\section{Referensi}

Baker, D. L., S.M. Siahaan, A.A. Sitompul. Pengantar Bahasa Ibrani. Ke-25. Jakarta: BPK Gunung Mulia, 2015.

Berkhof, Louis, and Teologi Sistimatika. Doktrin Tentang Gereja. Vol. 5. Jakarta: BPK GM, n.d.

Brueggemann, Walter. Teologi Perjanjian Lama: Kesaksian, Tangkisan, Pebelaam. Pertama. Yogyakarta: CV. Titian Galang Printika, 2009.

Buttrick, George Arthur (ed board). “The Interpretter's Bible, Vol.1.” New York: Nashville: Abingdon Press, 1952.

Carson, D A. New Bible Commentary. USA: Intervarsity Press, 1994.

Christoph, Barth, and Frommel Barth. Teologi Perjanjian Lama 2. Jakarta: BPK Gunung Mulia, 2016.

—. Theologi Perjanjian Lama 1. Jakarta: BPK Gunung Mulia, 2011.

Darmawan, I Putu Ayub. "Murid Yang Memuridkan" in Melaksanakan Amanat Agung Di Abad 21. Edited by I Putu Ayub Darmawan. Ungaran: Sekolah Tinggi Teologi Simpson, 2017.

Douglas, J.D. Ensiklopedi Alkitab Masa Kini, Jilid 1, A-L. Edited by F.F. Bruce. Leicester, England: The Inter-arsity Fellowship, 1982.

Enns, Paul. Moody Handbook of Theology. Edited by Rahmiati Tanudjaja (penerjemah). 5th ed. Malang: Literatur SAAT, 1989.

Gutrie, Donald. Tafsiran Alkitab Masa Kini 1, Kejadian-Ester. Jakarta: Yayasan Komunikasi Bina Kasih, 2000.

Harrison, Charles F. Pfeiffer dan Everett F. Commentary Alkitab Wycliffe. Jakarta: Gandum Mas, 2007.

Hoekema, AA. “Manusia: Ciptaan Menurut Gambar Allah.” Terj. Irwan (2003). http://www.momentum.or.id/images/files/Manusiacipataan.pdf.

Hoekema, Anthony A. Manusia: Ciptaan Menurut Gambar Allah. Kelima. Surabaya: Momentum, 2015.

James Strong, LL.D., S.T.D. The New Strong's Complete Dictionary of Bible Words. USA: Thomas Nelson Publisher, 1996. 
Karman, Yonky. Bunga Rampai Teologi Perjanjian Lama. Jakarta: BPK Gunung Mulia, 2013.

"Hidup Manusia Menurut Perjanjian Lama." Forum Biblika, Jurnal Ilmiah (2013).

LAI. Perjanjian Lama Ibrani - Indonesia. Kedua. Jakarta: Lembaga Alkitab Indonesia, 2002. http://www.alkitab.or.id.

Lase, Delipiter. "Education and Industrial Revolution 4.0." Handayani Journal PGSD FIP Unimed 10, no. 1 (2019): 48-62.

Lembaga Alkitab Indonesia. Perjanjian Lama Ibrani - Indonesia. Jakarta: LAI, 2002.

Maimonides, Moses, and Max Felshin. Moses Maimonides (Rambam). New York: Book Guild, 1956.

Osborn, Grant R. Spiral Hermeneutika, Pengantar Konprehensif Bagi Penafsiran Alkitab. Pertama. Surabaya: Penerbit Momentum, 2012.

Page H. Kelley. Ibrani Biblikal. Pertama. Surabaya: Penerbit Momentum, 2013.

R.C. Sproul (General Editor), Keith Mathison (Associate Editor), ed. The Reformation Study Bible. Lake Mary, FL, USA: Ligonier Ministry, 2005.

Robinson, D. "Understanding the 'Imago Dei'.," no. 24 February 2016 (2010).

Sigal, Phillip. Juadaism: The Evolution of a Faith. Edited by Lillian Sigal. 2nd Revise. Eerdmans Pub Co, 1988.

Strong, James. The New Strong's Complete Dictionary of Bible Words. USA: Thomas Nelson Publisher, 1996.

Telaumbanua, Tuhoni. "Kaum Milenial \& Kebudayaan Nias: Di Persimpangan Jalan.” Jurnal Sundermann 1, no. 1 (2019): 1-16.

Telnoni, J.A. Kejadian Pasal 1-11, Tafsiran Alkitab Kontekstual-Oikumenis. Ke-1. Jakarta: Bpk Gunung Mulia, 2017.

Tong, Stephen. Peta Dan Teladan Allah. Surabaya: Momentum, 2012.

Zaluchu, Sonny Eli. "Mengkritisi Teologi Sekularisasi." Kurios (Jurnal Teologi dan Pendidikan Agama Kristen Vol. 4, no. 1 April 2018 (2018): 26-38.

http://www.sttpb.ac.id/e-journal/index.php/kurios/article/view/31. 